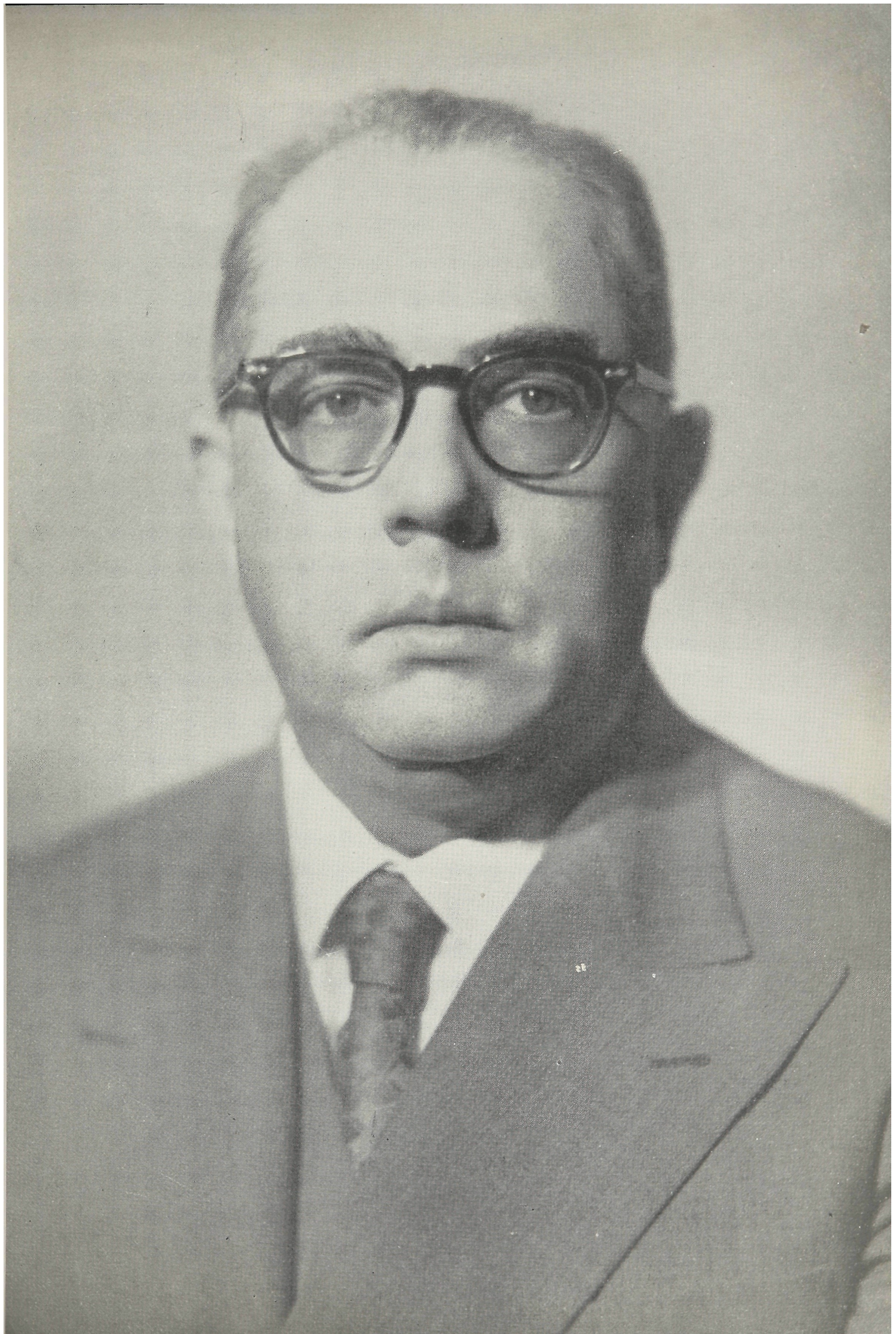




\section{Professor Dr. Noé Azevedo}

(Catedrático de Direito Penal.)

Noé Azevedo nasceu em Minas Gerais, a 16 de dezembro de 1896, na Fazenda Ariadnópolis, então pertencente ao Município de Dores da Boa Esperança, onde se acha registrado. Fêz o curso secundário no Liceu Municipal de Muzambinho. Diplomou-se pela Faculdade de Direito de São Paulo, em 1919, tendo defendido teses em 1921, obtendo, então, o grau de doutor em ciências juridicas e sociais. Foi aprovado em concurso para livre-docente de Direito Penal, em 1928, tendo dado a primeira aula, em substituição do Prof. Gama Cerqueira, a 3 de abril de 1929. Em 1936. fêz concurso para catedrático dessa disciplina sendo nomeado professor efetivo. Nesse mesmo ano, foi nomeado membro do Conselho Penitenciário, função que exerce até agora. Foi membro, durante vários anos do Conselho Têcnico e Administrativo da Faculdade. Como membro do Conselho do Instituto dos Advogados de São Paulo, integrou o Conselho Provisório da Ordem dos Advogados do Brasil, Seção de São Paulo, que foi criada em 1932. Eleito para o $1 .^{\circ}$ Conselho dessa instituição, por um biênı, foi reeleito no biênio seguinte, passando a ocupar: o cargo de Vice-Presidente. Quando faleceu o Professor Azevedo Marques, assumiu a Presidência dessa Instituição, e vem sendo reele to, de dois em dois anos, para o Conselho e para a Presidência, que atualmente ocupa. É membro. do Conselho da Inter-American Bar Association, desde 194: e representou os advogados de São Paulo em sete das oito Conferências realizadas por essa entidade, em vários países da América do Norte e do Sul. Ł̌ Membro-Patrono da 
International Bar Association, tendo comparecido às Conferências da mesma, realizadas em Londres, em 1950. e em Madrid, em 1952. Em 1950, representou o Conselho Penitenciário de São Paulo e a Faculdade de Direito no XII Congresso Penal e Penitenciário, realizado em Haia, e na Conferência Internacional de Criminologia, realizada em Paris. Em 1952, compareceu como representante do Conselho Penitenciário de São Paulo e da Faculdade, esta também representada pelo Prof. Soares de Mello, ao Congresso Hispano-Luso-Latino-Americano-Filipino Penal e Penitenciário, realizado em Madrid. Foi um dos representantes de São Paulo no Congresso Jurídico Nacional de 1943, reunido no Rio de Janeiro. É membro de várias sociedades e associacões jurídicas e culturais, nacionais e estrangeiras. Dirige a "Revista dos Tribunais". tendo dedicado à mesma quase tôda a sua atividade intelectual, até 1933, quando foi chamado à regência de cadeiras na Faculdade de Direito. Além dos trabalhos de redação, registra a "Revista dos Tribunais" numerosos pareceres, artigos e comentários por êle assinados. Quando estudante, colaborou em vários jornais acadêmicos. sendo eleito durante dois anos para a comissão de redação do "XI de Agôsto", tendo conseguido, com o concurso de Vicente de Azevedo, Soares de Mello e outros, imprimir dois alentados fascículos dessa publicação. $\mathrm{E}$, quando estudante ainda, iniciou a sua colaboração na "A Gazeta", tratando sempre de assuntos sociais e pedagógicos. Em 1920, iniciou a sua atividade de cronista forense, resumindo os debates dos casos mais interessantes julgados pelo Tribunal de Justiça de São Paulo, a princípio para o "Jornal do Comércio de São Paulo", e de 1924 até 1934 para "O Estado de São Paulo". Durante os anos de 1944 e 1945 escreveu, semanalmente. um rodapé para a "Fôlha da Manhã". sob a epigrafe "Notas Jurídicas", tendo sido as do primeiro ano publicadas em volume com êsse título. Como livros. publicou, em 1920, a sua dissertação para a defesa de teses, 
intitulada "Dos Tribunais Especiais para Menores"; em 1927, um opúsculo sôbre "A Socialização do Direito Penal", e, em 1936, “As Garantias da Liberdade Individual”. Fêz imprimir, em folhetos e plaquetes, vários discursos, conferências e comunicações a congressos jurídicos, nacionais e internacionais. Dão conta da sua atividade intelectual como advogado mais de duas centenas de folhetos e opúsculos publicados. Alguns dentre êles constituem alentados estudos monográficos, como os que tratam "Da Prova na Investigação da Paternidade", "Denúncia Caluniosa". "A Fraude Derroga tôdas as Regras", "Do Stoppage in Transitu", "Do Conhecimento Marítimo", "Capacidade Eventual da Prole para Adquirir por Testamento", "Da Redação do Testamento Público". "Contrafação de Patente de Invenção", "Caducidade de Legado", "Reivindicatória Fundada em Domínio Derivado", "A Questão do Sigilo Bancário", "Da Prova nas Ações de Reivindicação", "Contratos Confirmados e Ratificados por Testamento", etc. 